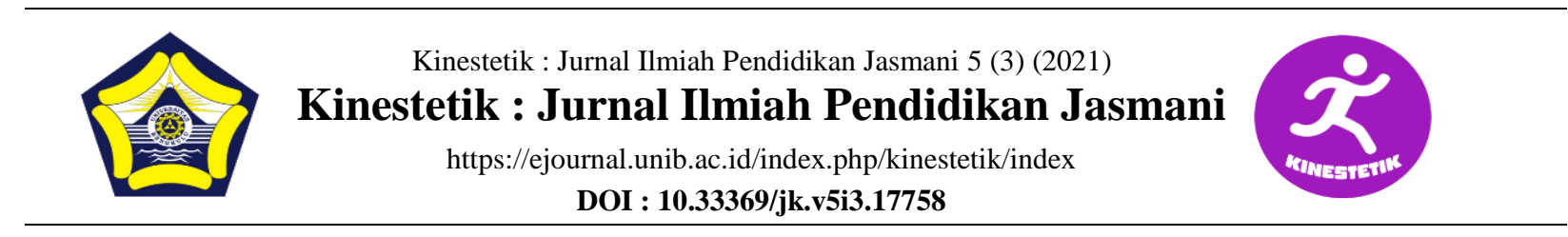

\title{
UTILIZATION OF MEDIA IN PHYSICAL EDUCATION LEARNING FOR ELEMENTARY SCHOOL STUDENTS
}

\author{
Silvi Aryanti' ${ }^{1 *}$, Samsul Azhar ${ }^{2}$, Ahmad Rifai Azani ${ }^{3}$, Wahyu Indra Bayu ${ }^{4}$, Bogy Restu \\ Ilahi $^{5}$
}

${ }^{1,4}$ Physical Education, Health, and Recreation, Faculty of Teacher Training and Education, Universitas Sriwijaya, Indonesia

${ }^{2,3}$ Primary Teacher Education, Faculty of Teacher Training and Education, Universitas Muhammadiyah Tangerang, Indonesia

${ }^{5}$ Physical Education and Health, Faculty of Teacher Training and Education, Universitas Bengkulu, Indonesia

\section{Article Info}

Article History :

Received : September 2021

Revised : September 2021

Accepted : September 2021

Available online : September 2021

Keywords:

Media, Sparkol Videoscribe, Physical Education, Elementary School

\begin{abstract}
The purpose of this study was to determine the use of learning media, namely using Sparkol Videoscribe in Physical Education learning for elementary school students of class V MI Nurul Yaqiin. This research is a qualitative research with descriptive method. Data analysis using observation, interviews and documentation. The research subjects used 22 fifth grade students. The results showed that the use of learning media using Sparkol Videoscribe was good and quite interesting. The material can be understood even though the learning is done from home. The existence of sparkol videoscribe-based learning media, the steps of the practical material presented by the teacher can be seen. The results of the practice carried out by students and then students send videos through the whatsapp group can be seen that students are able to practice the material according to the steps correctly. The Sparkol Videoscribe learning media can make physical education learning interesting and varied. The material provided by the teacher is not monotonous and the students are very interested in participating in the learning. The implication of this research is that sparkol videoscribe-based learning media can be used for learning physical education for elementary school students.
\end{abstract}

Corresponding address : Jl. Masjid Al Gazali, Bukit Lama, Kec.

Ilir Bar. I, Kota Palembang, Sumatera Selatan 30128

*Corresponding email : silviaryanti@fkip.unsri.ac.id
ISSN 2685-6514 (Online)

ISSN 2477-331X (Print) 


\section{INTRODUCTION}

Sport is a part of history that cannot be separated from humans. Sport has a function, namely as the progress of civilization and a measuring instrument for ideals in an effort to improve the quality of human life physically, spiritually and socially. Through sports the human mind can be improved. There are several kinds of sports, one of which is educational sports. Undang-Undang Pemerintah No. 3 Tahun 2005, the national sports system contains educational sports, namely physical education and sports whose implementation is carried out as part of an orderly and continuous educational process. This is in order to obtain knowledge, personality, skills, health, and physical fitness.

Learning is part of education at the level of the education unit, both in elementary schools, junior high schools, senior high/vocational schools. When learning, a teacher must prepare learning media. Including learning media, namely video. Aryanata, et. (2020) Learning video media will greatly facilitate students in understanding the material delivered by the teacher The use of fun thinkers media based on question forms for grade 1 elementary school students in theme 3 of my activity obtained a decent category. Rosnata, etc (2020) Therefore, fun media can be applied to learning. It is used in learning so that students can be helped. Based on expert opinion, it can be concluded that students and teachers in the learning process are greatly helped by the existence of learning media. Students become more enthusiastic in the teaching and learning process, helping students in understanding the material, the learning process is more effective and efficient, so that learning objectives can be achieved.

One of the learning media that can be used for learning is Sparkol Videoscribe. Al-Munawaroh (2019) Sparkol videoscribe is an app web-based software that can be used to design animated presentations. Sparkol Videoscribe is a software application that produces video formats that combine concept maps, images, sounds, and music. So that students are interested in following the lesson. Azizah (2018) The results of the study when the teacher applied the sparkol videoscribe learning media obtained that there was an increase in student interest in learning. This can be seen from the measurement of the increase in student interest in learning through the n-gain test with good results of $0.76, \mathrm{~d}$ the teacher's opinion obtained by the n-gain test of 0.75. According to Yandari et al. (2018) states that making Sparkol VideoScribe media can be online or offline. This makes it independent of the internet. Aryanti (2020) the use of learning media in the form of animated videos can improve student learning with badminton material. Pamungkas, et.l, (2018) Sparkol videoscribe is an animated video learning media containing a series of images. which is used as a series of videos as a whole. Learning content presented using Sparkol Videoscribe is mixed and 
matched with attractive images, sounds and designs. This makes the learning process enjoyable for students.

Results of observations when the teacher delivered soccer material to the fifth grade students of MI Nurul Yaqii, the teacher dominated during learning, while the role of the students was not very involved. The learning media presented by the teacher is still very minimal, namely in the form of illustration media in books and the teacher demonstrates. This makes learning less interesting and the emergence of learning saturation.

Based on the current problem, learning media is needed that can help elementary school students of class $\mathrm{V}$ MI Nurul Yaqiin understand the material. Learning media that can be used by teachers is Sparkol Video Subscribe.

\section{METHODS}

This research is a qualitative research with descriptive method and naturalistic approach. The research was conducted at MI Nurul Yaqiin, Tangerang city. Qualitative method is a method based on post positivism philosophy, aiming for the natural condition of the object under study, (as opposed to experiment) the researcher is the key instrument, sampling of data sources is carried out purposively and snowboal, the collection technique is triangulation (combined), data analysis is descriptive. inductive or qualitative, and qualitative research results emphasize meaning rather than generalization.

\section{Participants}

The subjects of this study were the students of class V MI Nurul Yaqiin, totaling 22 people. In addition to students, the research subject is a physical education teacher who teaches class V.

\section{Sampling Procedures}

The subjects of this study were 22 students of class V MI Nurul Yaqiin. Subjects were taken using purposive sampling technique. Sugiyono (2016:85) purposive sampling is a sampling technique between data sources with consideration first.

\section{Materials and Apparatus}

The instruments used for interviews in this study are as follows:

Table 1. Interview Instruments to Class V . Students

\begin{tabular}{cl}
\hline No & \multicolumn{1}{c}{ Question } \\
\hline 1 & $\begin{array}{l}\text { What is your opinion regarding the } \\
\text { application of the Sparkol Videoscribe } \\
\text { learning media? }\end{array}$ \\
\hline 2 & $\begin{array}{l}\text { What is your opinion about learning } \\
\text { Physical education using the Sparkol } \\
\text { Videoscribe learning media? }\end{array}$ \\
\hline 3 & $\begin{array}{l}\text { Have you ever seen a teacher using the } \\
\text { Sparkol Videoscribe learning media in } \\
\text { learning? }\end{array}$ \\
\hline 4 & $\begin{array}{l}\text { What is your opinion about the teacher's } \\
\text { teaching style when using the Sparkol } \\
\text { Videoscribe learning media? }\end{array}$ \\
\hline 5 & $\begin{array}{l}\text { Are you enthusiastic when learning using } \\
\text { the Sparkol Videoscribe learning media? }\end{array}$ \\
\hline 6 & $\begin{array}{l}\text { Is learning fun and active with the } \\
\text { Sparkol Videoscribe learning media? }\end{array}$ \\
\hline 7 & $\begin{array}{l}\text { Do you find it easier to understand } \\
\text { learning by using the Sparkol Videoscribe } \\
\text { learning media? }\end{array}$ \\
\hline 8 & $\begin{array}{l}\text { Can you practice the material after you } \\
\text { see the explanation through the Sparkol } \\
\text { Videoscribe learning media? }\end{array}$ \\
\hline 9 & $\begin{array}{l}\text { What are the obstacles experienced when } \\
\text { using the Sparkol Videoscribe learning } \\
\text { media? }\end{array}$ \\
\hline 10 & $\begin{array}{l}\text { Can after using the Sparkol Videoscribe } \\
\text { learning media grow your interest in } \\
\text { learning? }\end{array}$ \\
\hline &
\end{tabular}




\section{Procedures}

There are five stages used in this study, namely as follows: 1). Instrument manufacture, making research instruments because is very important so that when data collection is clearer and easier. The instrument made is an interview instrument conducted to fifth grade students and physical education teachers. The second instrument is used for observation during data collection. 2) Create the object to be studied, the objects to be studied are elementary school students of class V MI Nurul Yaqiin Tangerang city and physical education teachers when giving soccer material. 3) Collecting data from the object under study, after students collect learning media using sparkol videoscribe, then the tasks are collected into one. 4) Process and analyze the data that has been collected, the next stage is after the data has been obtained, data processing is carried out and the data is analyzed whether sparkol videoscribe is in accordance with the stages of manufacture. 5) Concluding from the research that has been done.

The last stage is making conclusions about the implementation of the research and sparkol videoscribe made by students by viewing the video display, interest, and creativity.

\section{Design or Data Analysis}

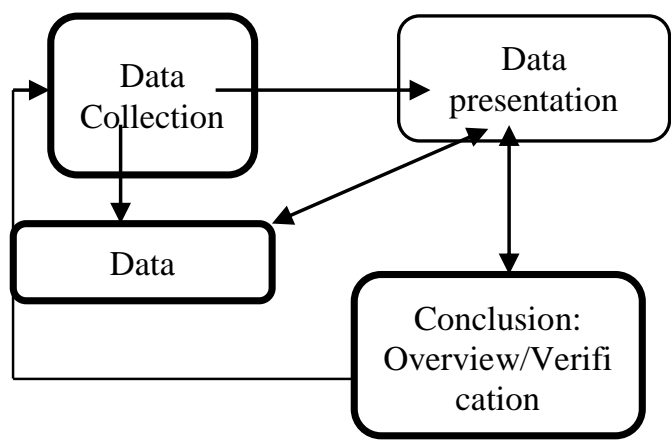

This study uses a qualitative analysis model from the Miles \& Huberman model (2014), which is as follows:

\section{Data Reduction}

Data reduction includes summarizing, choosing the main things and focusing on the important things. Aims to find themes and patterns from obtaining the amount of data in the field. Obtaining research data is by observation, interviews, and documentation which is then reduced. Therefore, it can help to provide a clearer and easier picture for further data collection.

\section{Data Presentation}

Presentation of data in qualitative research is usually done in the form of brief descriptions, charts, relationships between categories and others. Aim for the reader easy and understand what happened and draw conclusions.

\section{Conclusion}

Conclusions in qualitative research are answered in the formulation of the problem from the start. Conclusions are new findings that have never existed before. These findings can be in the form of a description or description of an object that was previously still vague or dark so that the research becomes clear, it can be in the form of interactive relationships, hypotheses or theories.

\section{RESULTS}

To obtain research data, interviews were conducted with the fifth grade teacher of MI Nurul Yaqiin, it was found that students had problems, namely the limited space due to online learning. 
Students have complaints when practicing the material presented by the teacher.

Interview Result

\section{Interview with Physical Education Teachers}

The results of the researcher's interview with the physical education teacher showed that the Sparkol Videoscribe learning media was easy to use. The media is distributed to students through whats app groups and then provides an explanation to students. The Sparkol Videoscribe learning media makes learning more varied and effective, and makes it easier for students as a guide when the material will be practiced.

Learning materials do not need to be delivered by the teacher, because all explanations are designed in Sparkol Videoscribe media. Make students during the learning process see and make observations. When delivering material by the teacher using the Sparkol Videoscribe learning media and seen when students practice football material that has been sent via video in the whatsapp group, it can be seen that students are enthusiastic and given positive responses regarding the Sparkol Videocribe media. Some students when practicing found that students already understood the material given. The use of learning media Sparkol Videoscribe learning objectives in dribbling material can be achieved, this can be seen during the initial and final attitude in the dribbling technique.

\section{Interview with Students}

Interviews were conducted on fifth grade students of MI Nurul Yaqiin. The results of the interviews that have been obtained are: interviews were conducted on 22 fifth grade students of mi nurul yaqiin, the results obtained were the use of learning media in the form of sparkol videoscribe which was very good, interesting and the video was easy to understand. the sparkol videoscribe learning media can help students easily understand theoretical material.

Previous students did not know about the sparkol videoscribe learning media. the implementation of the sparkol videoscribe learning media makes students more enthusiastic about learning, having fun, and growing interest in learning. this is because in delivering the material there are voice actors so that the material is delivered, animations to make students interested, and also physical education learning practice videos to make it easier for educational materials to be practiced.

Discussion

The use of videos for learning can have benefits for students in understanding the material provided by the teacher (Aryanti, etc (2021). Learning media using video makes students understand the material given by the teacher. the type of video used is sparkol subscribe. this research uses learning media, namely sparkol subscribe for soccer dribble material for class V MI Nurul Yaqiin.

The results showed that there was a significant effect of sparkol videoscribe-based learning media on student learning outcomes, and sparkol videoscribe-based learning media were effective when used in the learning 
process (Jannah, etc, 2019). Learning tools used sparkol videoscribe an increase in student learning outcomes and critical thinking skills. This makes learning enjoyable for students. By using video learning media, it is expected that physics can be a fun lesson (rachmawati et al, 2016). The findings of this study are that the learning model using sparkol videoscribe software makes one alternative so that students' mathematical understanding is improved (Widayanti, 2019).

\section{CONCLUSION}

Carrying out physical education learning by using the Sparkol Videoscribe learning media in class $\mathrm{V}$ MI Nurul Yaqiin makes it easier for teachers to deliver material about football.

\section{REFERENCES}

Al Munawarah, R. (2019). Sparkol Videoscribe Sebagai Media Pembelajaran. Jurnal Inspiratif Pendidikan, 8(2), 430-437.

Aryanata, I. W. Y., Jampel, I. N., \& Mahadewi, L. P. P. (2020). Media Video Pembelajaran Teknik Dasar Bermain Bola Voli Pada Pelajaran Penjaskes. Jurnal Penelitian dan Pengembangan Pendidikan, 4(2), 186-192.

Aryanti, S., Victorian, A. R., \& Bayu, W. I. (2021). Learning of Sepak Sila Technique Based Video For Sepak Takraw Course.

Aryanti, S., \& Hartati, S. (2020). Learning of Badminton Model through Animation Video on Physical Education Students.

Azizah, A. N. (2018). Pengembangan media pembelajaran sparkol videoscribe dalam meningkatkan minat belajar siswa pada mata pelajaran ekonomi materi perdagangan internasional di sma batik 2 surakarta (Doctoral dissertation, Universitas

Muhammadiyah Surakarta).

Jannah, M., Harijanto, A., \& Yushardi, Y. (2019). Aplikasi Media Pembelajaran Fisika Berbasis Sparkol Videoscribe Pada Pokok Bahasan Suhu Dan Kalor Terhadap Hasil Belajar Siswa SMK. Jurnal Pembelajaran Fisika, 8(2), 65-72.

Miles, M.B, Huberman, A.M, \& Saldana, J. (2014). Qualitative Data Analysis, A Methods Sourcebook, Edition 3. USA: Sage Publications. Terjemahan Tjetjep Rohindi Rohidi, UI-Press.

Pamungkas, A. S., Ihsanudin, I., Novaliyosi, N., \& Yandari, I. A. V. (2018). Video pembelajaran berbasis sparkol videoscribe: Inovasi pada perkuliahan sejarah matematika. Prima: Jurnal Pendidikan Matematika,2(2), 127135.

Rahmawati, F., Soegimin. Soeparman, K. 2016. Pengembangan Perangkat Pembelajaran Fisika Model Inkuiri Terbimbing Berbantuan VideoScribe Pada Materi Kalor Untuk Meningkatkan Hasil Belajar Siswa Sman 1 Kedungwaru. Jurnal Pendidikan Fisika. 5 (2).

Rosnata, N. P. F. M. B., Agustiana, I. G. A. T., \& Dibia, I. K. (2021). Innovative Learning Through Fun Thinkers Media Based On Fill The Blank Question. International Journal of Elementary Education, 5(3).

Sugiyono. 2018. Metode Penelitian Kuantitatif, Kualitatif, dan R\&D. Bandung: Alfabeta.

Sugiyono. (2016). Metode Penelitian Kuantitatif, Kualitatif dan R\&D. Bandung: Alfabeta.

Undang- undang RI No 3 Tahun 2005 Tentang Sistem Keolahragaan Nasional. Kementrian.Negara Pemuda dan Olahraga Republik Indonesia.

Widayanti, E., \& Aisyah, S. (2019). Penerapan Model Pembelajaran Treffinger Berbantukan Software Sparkol Videoscribe Untuk Meningkatkan Pemahaman Matematis 
Siswa. Kalamatika: Jurnal Pendidikan Matematika, 4(2), 117-128.

Yandari, V. A., Novaliyosi, Ihsanodin, Pamungkas, S. A. 2018. Video Pembelajaran Berbasis Sparkol VideoScribe Inovasi Pada Perkuliahan Sejarah Matematika. Jurnal Pendidikan Matematika. 2(2): 12713.A 